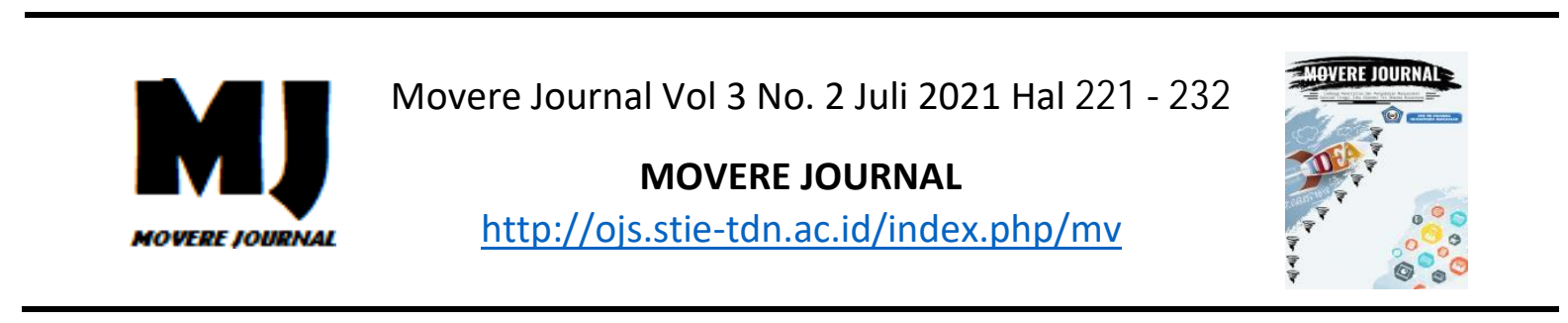

\title{
Analisis Manfaat Seleksi Karyawan Terhadap Produktivitas Dan Efektivitas Kerja Karyawan Pada Bidang Perhotelan Di Kota Makassar
}

\author{
${ }^{1}$ Hendra Gunawan \\ ${ }^{1}$ STIE AMKOP Makassar \\ Email : hendramanajemen@gmail.com
}

\begin{abstract}
Abstrak: Tujuan penelitian untuk mengkaji karakteristik seleksi karyawan terhadap produktivitas karyawan dan efektivitas. Populasi penelitian ini adalah karyawan hotel di Makassar, jumlah sampel , responden sebanyak 75 orang karyawan hotel. Metode analisis yang digunakan a Statistik Deskriptif dan Analisis Regresi Linear. Hasil penelitian menjelaskan terdapat pengaruh positif antara variabel seleksi tenaga kerja terhadap produktivitas karyawan dan efektivitas. Hasil Pengujian koefisien determinasi diperoleh nilai adjusted $R$ square adalah 0,440 . Hal ini menunjukkan bahwa sebesar $44 \%$ seleksi karwayan dipengaruhi oleh variasi kedua variabel, yaitu produktivitas karyawan (Y1), dan Efektivitas (Y2). Sedangkan sisanya sebesar 56\% dipengaruhi oleh variabel-variabel lainnya yang tidak diteliti. Hasil perhitungan uji-t diketahui bahwa dari variabel produktivitas diperoleh nilai thitung sebesar 2,887, dimana t-tabel sebesar 1,666 berarti t-hitung > dari t-tabel sehingga dapat disimpulkan bahwa terdapat pengaruh positif dan signifikan antara produktivitas karyawan sebagai veriabel yang berpengaruh terhadap seleksi tenaga kerja, hasil uji-t varibel efektivitas diperoleh nilai thitung sebesar 3,870, dimana t-tabel sebesar 1,666 berarti t-hitung > dari t-tabel sehingga disimpulkan terdapat pengaruh positif dan signifikan antara efektivitas sebagai veriabel yang berpengaruh terhadap seleksi tenaga kerja. Hasil perhitungan menggunakan program SPSS Ver 22.00 diperoleh F-hitung sebesar 2,232. Hal ini menunjukkan bahwa F-hitung > F-tabel yang berarti bahwa terdapat hubungan yang signifikan secara serempak antara variabel penelitian Seleksi karyawan terhadap Produktivtas dan Efektivitas pada karyawan hotel Makassar.
\end{abstract}

Kata Kunci: manfaat ; seleksi karyawan ; produktivitas karyawan

Abstract: The purpose of this research is to examine the characteristics of employee selection on employee productivity and effectiveness. The population of this study were hotel employees in Makassar, the number of samples, respondents were 75 hotel employees. The analytical methods used are Descriptive Statistics and Linear Regression Analysis. The results of the study explain that there is a positive influence between labor selection variables on employee productivity and effectiveness. The results of the determination coefficient test obtained that the adjusted $R$ square value was 0.440 . This shows that $44 \%$ of employee selection is influenced by variations in the two variables, namely employee productivity (Y1), and effectiveness (Y2). While the remaining 56\% is influenced by other variables not examined. The results of the t-test calculation show that from the productivity variable, the t-count value is 2.887 , where the t-table is 1.666 means $t$-count $>$ from $t$-table so it can be concluded that there is a positive and significant influence between employee productivity as a variable that has an effect on labor selection, the results of the t-test of the effectiveness variable obtained a t-count value of 3.870, where the t-table of 1.666 means $t$-count $>$ from $t$-table so that it is 
concluded that there is a positive and significant effect between effectiveness as a variable that affects labor selection. The results of calculations using the SPSS Ver 22.00 program obtained an F-count of 2.232. This shows that F-count > F-table which means that there is a simultaneous significant relationship between the research variables Employee Selection on Productivity and Effectiveness of Makassar hotel employees.

Keywords : benefit ; employee selection; employee productivity 


\section{A. PENDAHULUAN}

Hotel adalah suatu bidang komersial dimana terdapat layanan kamar, makanan dan minuman yang dijual kepada wisatawan yang melakukan perjalanan dan sanggup membayar dengan nominal yang patut karena telah mendapatkan pelayanan yang baik tanpa ada perjanjian khusus. Guna tercapainya harapan dan kepuasan saat tamu menginap di hotel, karyawan yang baik harus memenuhi harapan tamu tersebut. Karyawan dalam bekerja harus memiliki sumber daya yang baik yang mampu menunjang produktivitas kerja dan kinerja yang diharapkan oleh pihak manajemen. Salah satu cara untuk menunjang produktivitas karyawan dalam bekerja diperlukan pengelolaan Sumber Daya Manusia (SDM), Sulastiyoono (2011).

Menurut Larasati

Manajemen Sumber Daya Manusia (SDM) saat ini amat dibutuhkan jika berbicara tentang bisnis perhotelan, karena dengan pengelolaan sumber daya manusia yang bagus kelompok perusahaan bakal menjadi semakin baik. Sumber Daya Manusia (SDM) merupakan komponen utama pada sebuah kelompok, apapun wujud dan tujuannya, kelompok dibuat berlandaskan dari berbagai visi, misi dan target kepada kebutuhan individu dan dalam penerapan misinya dikelola dan diurus oleh individu, jadi individu merupakan komponen utama dalam semua rencana institusi/ kelompok.

Produktivitas memiliki dua dimensi produktifitas kinerja yakni efektifitas dan efesiensi. Dimensi pertama berkaitan dengan pencapaian untuk kinerja yang maksimal,dalam arti pencapaian target yang berkaitan dengan kualitas, kuantitas dan waktu sedangkan dimensi kedua berkaitan dengan upaya membandingkan masukan dengan realisasi penggunaannya atau bagaimana pekerjaan tersebut dilaksanakan
(Sedarmayanti, 2009:58)

Seleksi sangat penting dilakukan bagi perusahaan, dengan harapan agar mendapatkan karyawan yang dapat bekerja dengan baik dan memiliki produktivitas yang tinggi serta mampu menjabarkan visi dan misi yang telah disepakati bersama dalam rangka pencapaian tujuan perusahaan.

Tindakan perusahaan untuk menyeleksi calon karyawan yang akan dipekerjakan sangatlah tepat, karena dengan adanya proses seleksi perusahaan akan melihat skill atau kemampuan para calon karyawan dengan begitu perusahaan dapat memilih orang yang tepat yang akan dipekerjakan didalam suatu perusahaan. Karena dengan mendapatkan karyawan yang tepat maka perusahaan mempunyai asset yang sangat mahal yang tidak bisa dinilai dengan uang, dengan adanya sumber daya manusia yang mempunyai kemampuan atau prestasi kerja yang tinggi.

Di Sulawesi selatan banyak terdapat hotel berbintang khususnya di kota Makassar. Hotel yang memiliki fasilitas yang cukup memuaskan para pengunjung hotel, oleh karena itu fasilitas dan pelayanannya yang memuaskan, banyak pengunjung yang menginap di hotel tersebut sehingga pihak manajemen masih membutuhkan karyawan tambahan untuk melayani para pengunjung.

Salah satu jalan untuk mendapatkan karyawan yang kreatif, inovatif, dan efektif guna meningkatkan produktivitas perusahaan adalah dengan cara memilih calon karyawan yang akan dipekerjakan untuk mendapatkan karyawan yang diinginkan oleh perusahan. Seleksi tenaga kerja dilakukan untuk mengisi lowongan yang ada melalui prosedur dan sistem seleksi yang efektif dilakukan sesuai tujuan dengan peraturan dan cara yang benar terhadap calon karyawan yang memiliki kualitas dan mampu merealisasikan tujuan perusahaan sehingga diharapkan dapat tumbuh berkembang sesuai dengan tujuan yag telah ditetapkan perusahaan.

Produktivitas dan efektivitas kerja 
karyawan merupakan hal yang sangat penting untuk dijadikan sebagai tolok ukur berhasil tidaknya pelaksanaan seleksi tenaga kerja yang telah dilakukan perusahaan pada karyawannya. Peneliti mendapatkan kenyataan di karyawan hotel dalam seleksi tenaga kerja kurang teliti. Hal ini dapat dilihat ketika peneliti mengadakan survey awal dengan mewawancarai sebagian karyawan dan melihat dari pelayanannya terhadap pelanggan, dimana pada masing-masing bagian tersebut terdapat ketidaksesuaian antara keahlian dengan pekerjaan yang diembannya, dan dalam penempatan karyawan kurang terfokus pada kebutuhan di masing-masing

\section{B. TELAAH LITERATUR DAN PENGEMBANGAN HIPOTESIS}

\section{Seleksi Karyawan}

Seleksi adalah serangkaian proses kegiatan yang digunakan untuk memutuskan apakah pelamar diterima atau tidak. Proses seleksi dimulai setelah kumpulan para pelamar yang memenuhi syarat yang didapatkan melalui rekrutmen. Proses ini melibatkan serangkaian tahap yang menambah kompleksitas dan waktu sebelum waktu pengadaan personalia diambil. Bila seleksi dilaksanakan dengan tidak tepat,upaya - upaya sebelumnya yang dilakukan akan sia - sia.

Seleksi adalah kunci sukses manajemen personalia, dan bahkan sukses organisasi. (Handoko, $2010: 85$ ) Menurut Yani ( 2012 : 66 ) menyatakan bahwa proses seleksi adalah proses pemilihan calon tenaga kerja yang paling memenuhi syarat untuk mengisi lowongan pekerjaan. Menurut Ike ( 2008 : 100 ) menyatakan bahwa seleksi merupakan proses dua arah dimana organisasi menawarkan posisi kerja dengan kompensasi yang layak, sedangkan sub bagian, selain itu terdapat beberapa karyawan yang beban kerjanya satu dengan yang lainnya berbeda sehingga terkadang menimbulkan perasaan tidak puas. Karyawan dalam menjalankan pekerjaannya tidak semuanya sesuai dengan apa yang diinginkan perusahaan sehingga kualitas pelayanan yang dihasilkan menjadi kurang baik dan masih saja terdapat ketidaksesuaian antara cara kerja para karyawan dengan cara kerja yang ditetapkan oleh perusahaan.

calon pelamar mngevaluasiorganisasi dan daya tarik posisi serta imbalan yang ditawarkan oleh organisasi.

Menurut Rivai (2009:148), rekrutmen sebagai suatu rangkaian kegiatan yang dimulai ketika sebuah perusahaan memerlukan tenaga kerja dan membuka lowongan pekerjaan sampai mendapatkan calon yang diinginkan atau memenuhi kualifikasi sesuai dengan jabatan atau lowongan yang ada. Sementara menurut Hasibuan (2011:28), rekrutmen adalah proses penarikan, seleksi, penempatan, orientasi dan induksi untuk mendapatkan karyawan yang efektif dan efisien membantu tercapainya tujuan perusahaan. Menurut Mardianto (2014:8) diartikan sebagai suatu proses untuk mendapatkan calon karyawan yang memiliki kemampuan yang sesuai dengan kualifikasi dan kebutuhan suatu organisasi/perusahaan. Proses rekrutmen tidak hanya menarik minat seseorang untuk bekerja pada perusahaan tersebut, tetapi juga memperbesar kemungkinan untuk mempertahankan calon karyawan yang akan menjadi karyawan setelah mereka bekerja. Pada intinya rekrutmen merupakan usaha yang dilakukan untuk memperoleh sumber daya manusia yang dibutuhkan dalam mengisi jabatan 
tertentu yang masih kosong. (Nurmansyah, 2011:71) yang mendefinisikan rekrutmen sebagai kegiatan untuk mendapatkan tenaga kerja baru untuk mengisi lowonganlowongan jabatan yang ada pada unit-unit dalam perusahaan.

Tujuan rekrutmen menurut Rivai (2009:150) adalah menerima pelamar sebanyak - banyaknya sesuai dengan kualifikasi kebutuhan perusahaan dari berbagai sumber, sehingga memungkinkan akan terjaring calon karyawan dengan kualitas tertinggi dari yang terbaik. Sehingga diharapkan calon karyawan tersebut akan dapat menyelesaikan tugas dan pekerjaan yang dibebankan kepadanya dengan cara se-efisien dan se-efektif mungkin guna tercapainya tujuan.

Produktivitas Kerja Masalah produktivitas adalah masalah yang sangat penting untuk saat ini. Masyarakat semakin sadar bahwa produktivitas dapat meningkatkan kesejahteraan manusia. Pentingnya produktivitas kerja mencakup banyak hal seperti produktivitas tenaga kerja, produktivitas organisasi, produktivitas pemasaran dan sebagainya. Secara umum, pengertian produktivitas menyangkut hubungan antara keluaran dengan masukan yang digunakan. Istilah produktivitas sering kacau dengan istilah produksi.

Banyak yang berpendapat bahwa semakin besar produksinya, semakin besar produktivitasnya. Para pakar pada umumnya sependapat bahwa produktivitas ialah output per unit, atau output dibagi input, atau rasio antara output dengan input.

Menurut Sinungan (2014:17) mengemukakan bahwa Produktivitas adalah suatu konsep yang bersifat universal yang bertujuan untuk menyediakan lebih banyak barang dan jasa yang akan digunakan oleh banyak manusia, dengan menggunakan sumbersumber riil yang semakin sedikit.
Adapun pengertian produktivitas kerja menurut beberapa ahli :

1. Danang Sunyoto (2012:203) Produktivitas kerja adalah ukuran yang menunjukkan pertimbangan antara input dan output yang dikeluarkan perusahaan serta peran tenaga kerja yang dimiliki persatuan waktu.

2. Muchdarsyah dalam Sedarmayanti (2011:198) produktivitas diartikan sebagai hubungan antara hasil nyata maupun fisik (barang) atau jasa dengan masukan sebenarnya.

3. Malayu S.P. Hasibuan (2012:94) produktivitas kerja adalah perbandingan antara output-nya harus mempunyai nilai tambah dan teknik pengerjaannya yang lebih baik. Berdasarkan pengertian diatas maka penulis dapat menyimpulkan bahwa produktivitas merupakan perbandingan hasil yang dicapai oleh seorang pekerja pada waktu tertentu dengan sumberdaya yang digunakan.

\section{Efektivitas Kerja}

Menurut Subagyo efektivitas adalah kesesuaian antara output dengan tujuan yang ditetapkan. Efektivitas adalah suatu keadaan yang terjadi karena dikehendaki. Menurut Ricard M. Steers, efektivitas harus dinilai atas dasar tujuan yang bisa dilaksanakan, bukan atas dasar konsep tujuan yang maksimum.

Menurut Liang Gie: Kalau seseorang melakukan suatu perbuatan dengan maksud tertentu dan memang dikehendaki, maka pekerjaan orang itu dikatakan efektif bila menimbulkan akibat atau mempunyai maksud sebagaimana yang dikehendaki sebelumnya. Dengan kata lain bahwa suatu hasil dikatakan mencapai efektivitas jika hasil tersebut benar-benar sesuai dengan rencana yang telah ditetapkan sebelumnya, termasuk ketentuan yang berlaku.

Menurut Emerson: Efektivitas merupakan penilaian hasil pengukuran dalam 
arti tercapainya tujuan yang telah ditetapkan sebelumnya. Efektifitas perlu diperhatikan sebab mempunyai efek yang besar terhadap kepentingan orang banyak. Efektivitas berarti bahwa tujuan yang telah direncanakan sebelumnya dapat tercapai atau dengan kata lain sasaran tercapai karena adanya proses kegiatan. Efektivitas juga dapat dipandang agar pelaksanaan administrasi lebih mencapai hasil seperti apa yang direncanakan, mencapai sasaran tujuan yang ingin dicapai dan lebih berhasil guna.

Dari pendapat para ahli diatas, dapat diambil kesimpulan efektivitas adalah alat ukur untuk mengetahui kemampuan seseorang dalam menyelesaikan tugas atau pekerjaannya. Apabila hasil dari pekerjaan itu sesuai dengan tuntutan yang ditetapkan diawal, maka hasil pekerjaan suatu individu itu bisa dikatakan efektif.

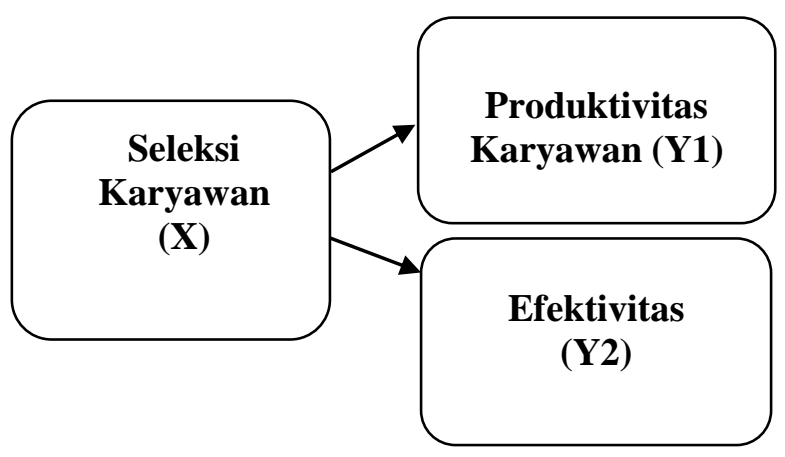

Gambar 1. Kerangka Konseptual

\section{METODE PENELITIAN}

Penelitin ini menggunakan pendekatan deskriptif kuantitatif yaitu melakukan penelitian dengan membawa permasalahan yang sudah jelas yang terumuskan dan dijawab dalam hipotesis. Penelitian ditujukan untuk mendeskripsikan fenomena-fenomena yang ada, baik fenomena alamiah maupun fenomena buatan manusia. Fenomena itu bisa berupa bentuk, aktifitas, karakteristik, perubahan, hubungan kesamaan, dan perbedaan antara fenomena yang satu dengan fenomena lainya.

Penelitian dilaksanakan pada seluruh hotel yang ada di Kota Makassar. Salah satu langkah dalam penelitian adalah menentukan obyek yang akan diteliti dan besarnya populasi yang ada. Populasi adalah kelompok subyek yang ingin digeneralisasikan dengan hasil penelitian. Populasi dalam penelitian ini adalah seluruh karyawan hotel yang ada di kota Makassar berjumlah 950 orang.

Sampel merupakan bagian dari jumlah dan karakteristik yang dimiliki oleh populasi tersebut. Pengambilan sampel dilakukan dengan teknik simple randomized sampling yaitu pengambilan sampel dilakukan secara acak tanpa memperhatikan strata yang ada dalam populasi itu. Jumlah sampel dalam penelitian ini ditentukan dengan menggunakan rumus Slovin, jumlah sampel dalam penelitian ini adalah 95 orang karyawan responden.

Tahapan-tahapan dalam analisis data adalah sebagai berikut: Analisis deskriptif dalam penelitian pada dasarnya merupakan proses transformasi data penelitian dalam bentuk tabulasi sehingga mudah dipahami dan di interpretasikan. Tabulasi menyajikan ringkasan, pengaturan atau penyusunan data dalam bentuk tabel numeric dan grafik. Analisis deskriptif umumnya digunakan oleh peneliti untuk memberikan informasi mengenai karakteristik variable penelitian utama. Ukuran yang digunakan adalah frekuensi, tendensi sentral (rata-rata, median, modus), disperse (deviasi standar dan varian) dan koefisen korelasi antar variable penelitian.

\section{Teknik Analisis Data dan Uji Hipotesis}

\section{Teknik Analisis Data}

Berdasarkan tujuan yang ingin dicapai dalam penelitian ini, maka data yang diperoleh akan diolah dan dipaparkan berdasarkan statistik deskriptif. Selanjutnya untuk kepentingan analisis dan pengujian hipotesis digunakan analisis jalur yang diolah menggunakan program SPSS : 
Menurut Sugiyono (2014:227) Persamaan analisis adalah sebagai berikut

$$
\begin{aligned}
& X=a+b_{1} Y_{1}+b_{1} Y_{2}+e \\
& X=a+b_{1} Y_{1} \\
& X=a+b_{1} Y_{2} \\
& X=Y_{1}+Y_{2}
\end{aligned}
$$

Dimana :

$$
\begin{aligned}
& \mathrm{X}=\text { Seleksi Tenaga Kerja } \\
& \mathrm{Y}_{1}=\text { Produktivitas Kerja } \\
& \mathrm{Y}_{2}=\text { Efektivitas } \\
& \mathrm{a}=\text { Konstanta } \\
& \mathrm{b}=\text { Koefisien regresi } \\
& \mathrm{e}=\text { Faktor Kesalahan (Asumsi=0) }
\end{aligned}
$$

2. Pengujian hipotesis

Uji parsial (uji t)

Uji parsial (uji t) digunakan untuk mengetahui pengaruh variabel bebas secara parsial atau sendiri-sendiri terhadap variabel terikatnya. Kriteria yang digunakan adalah:

1) Jika $t$ tabel $<\mathrm{t}$ hitung atau jika sig > 0,05, menunjukkan bahwa seleksi secara parsial tidak berpengaruh signifikan terhadap produktivitas dan efektivitas karyawan hotel

2) Jika t tabel $>$ t hitung atau jika sig $<0,05$, menunjukkan bahwa seleksi secara parsial berpengaruh signifikan terhadap produktivitas dan efektivitas karyawan hotel.

\section{HASIL DAN PEMBAHASAN}

Untuk menjawab rumusan masalah yang telah kami tetapkan pada bab I (Pendahuluan), serta menjawab hipotesis yang telah ditetapkan pada bab II sebelumnya, yaitu untuk mengetahui pengaruh seleksi tenaga kerja terhadap produktivitas karyawan dan efektivitas pada karyawan hotel Makassar, maka kami akan menggunakan model analisis regresi linear dengan melalui konversi hasil tabulasi skor jawaban responden pada lampiran 3 dengan metode perhitungan menggunakan program SPSS Versi 22.00.

Adapun formulasinya sebagai berikut :

\begin{tabular}{|c|c|c|c|c|c|c|c|c|}
\hline \multirow[b]{2}{*}{ Model } & \multicolumn{2}{|c|}{$\begin{array}{l}\text { Unstandardize } \\
\text { d Coefficients }\end{array}$} & $\begin{array}{l}\text { Standardized } \\
\text { Coefficients }\end{array}$ & \multirow[b]{2}{*}{$\mathrm{T}$} & \multirow[b]{2}{*}{ Sig. } & \multicolumn{3}{|c|}{ Correlations } \\
\hline & B & $\begin{array}{l}\text { Std. } \\
\text { Error }\end{array}$ & Beta & & & $\begin{array}{l}\text { Zero- } \\
\text { order }\end{array}$ & Partial & Part \\
\hline $1 \quad$ (Constant) & 6,229 & 1,158 & & $\overline{5,380}$ & ,000 & & & \\
\hline
\end{tabular}

$$
\begin{aligned}
& X=a+b_{1} Y_{1}+b_{1} Y_{2}+e \\
& X=a+b_{1} Y_{1} \\
& X=a+b_{1} Y_{2} \\
& X=Y_{1}+Y_{2}
\end{aligned}
$$

Dimana :

$$
\begin{aligned}
& \mathrm{X}=\text { Seleksi Tenaga Kerja } \\
& \mathrm{Y}_{1}=\text { Produktivitas Kerja } \\
& \mathrm{Y}_{2}=\text { Efektivitas } \\
& \mathrm{a}=\text { Konstanta } \\
& \mathrm{b}=\text { Koefisien regresi } \\
& \mathrm{e}=\text { Faktor Kesalahan (Asumsi=0) }
\end{aligned}
$$

Berdasarkan hasil perhitungan tersebut, maka hasil output yang diperoleh adalah sebagaimana pada tabel 4.14 berikut :

Tabel

Hasil Regresi Linear Menggunakan program SPSS Ver 22.00

Coefficients $^{\mathbf{a}}$ 


\begin{tabular}{|c|c|c|c|c|c|c|c|c|}
\hline $\begin{array}{l}\text { Produktivit } \\
\text { as } \\
\text { Karyawan }\end{array}$ & ,357 & , 124 & ,317 & 2,887 & ,005 & ,568 & ,322 & 255 \\
\hline Efektivitas & 450 & 116 & 424 & 3,870 &, 000 & ,612 & 415 & 341 \\
\hline
\end{tabular}

a. Dependent Variable: Seleksi Tenaga Kerja Sumber : Data primer 2021 (telah diolah)

Berdasarkan tabel tersebut, dapat ditulis dalam bentuk persamaan regresi bentuk Standar Koefisien diperoleh persamaan sebagai berikut :

$$
\begin{aligned}
& X=6,229+0,357+0,450 \\
& X=6,229+0,357 \\
& X=6,229+0,450 \\
& X=0,357+0,450
\end{aligned}
$$

Persamaan regresi tersebut dapat dijelaskan sebagai berikut :

1. Nilai constanta (a) diperoleh sebesar 6,229 yang berarti bahwa seleksi tenaga kerja pada karyawan hotel sebesar 6,229 poin tanpa adanya pengaruh variabel produktivitas karyawan dan efektivitas (Y1 dan Y2).

2. Variabel Produktivitas karyawan (Y1) berpengaruh positif terhadap seleksi tenaga kerja $(\mathrm{X})$ dengan nilai koefisien sebesar 0,357 yang berarti bahwa jika terjadi kenaikan tingkat produktivitas karyawan sebesar $1 \%$ maka kinerja karyawan juga akan mengalami kenaikan sebesar 0,357 dengan asumsi bahwa variabel lain (Y2) tetap.

3. Variabel Efektivitas (Y2) berpengaruh positif terhadap seleksi tenaga kerja (X) dengan nilai koefisien sebesar 0,450 yang berarti bahwa jika terjadi kenaikan tingkat efektivitas sebesar $1 \%$ maka kinerja karyawan juga akan mengalami kenaikan sebesar 0,450 dengan asumsi bahwa variabel lain (Y1) tetap.

\section{Uji Koefisien Determinasi (Adjusted $R$ square)}

Hasil perhitungan adjusted $R$ dapat diketahui berapa persentase yang dapat dijelaskan oleh variabel-variabel bebas terhadap variabel terikat. Sedangkan sisanya dipengaruhi atau dijelaskan oleh variabelvariabel lain yang tidak dimasukkan dalam metode penelitian.

Berikut ini adalah tabel hasil perhitungan koefisien determinasi dari hasil perhitungan menggunakan program SPSS Ver 22.00 :

Tabel

Koefisien Determinasi

Model Summary

\begin{tabular}{|l|r|r|r|r|}
\hline Model & \multicolumn{1}{|c|}{$\mathrm{R}$} & \multicolumn{1}{|c|}{ R Square } & Adjusted R Square & Std. Error of the Estimate \\
\hline & & & & \\
\hline 1 &, $663^{\mathrm{a}}$ &, 440 &, 424 &, 906 \\
\hline
\end{tabular}

Sumber : Data Primer 2021 (Hasil olah data)

Hasil perhitungan regresion menggunakan program SPSS Ver. 22.00 sebagaimana terlihat pada tabel 4.15 tersebut diketahui bahwa nilai adjusted $R$ square adalah 0,440 . Hal ini menunjukkan bahwa sebesar $44 \%$ seleksi tenaga kerja 
pada karyawan hotel Makassar dipengaruhi oleh variasi kedua variabel, yaitu Produktivitas Karyawan (Y1) dan Efektivitas (Y2), Sedangkan sisanya sebesar $56 \%$ dipengaruhi oleh variabel variabel lainnya yang tidak diteliti.

\section{Pengujian Serempak (Uji f)}

Pengujian hipotesis secara bersama sama atau serempak sering juga dikenal dengan istilah pengujian hipotesis secara simultan dengan menggunakan Uji F. Dari hasil pengujian dan perhitungan dengan mengunakan program SPSS Ver. 22.00 diperoleh data sebagaimana dapat dilihat pada tabel 4.16 berikut :

Tabel

Annova (output untuk mengetahui Uji F) Hasil SPSS Ver. 22.00

ANOVA $^{\mathrm{a}}$

\begin{tabular}{|ll|r|r|r|c|c|}
\hline Model & & Sum of Squares & Df & Mean Square & F & Sig. \\
\hline 1 & Regression & 46,321 & 2 & 23,161 & 28,232 &, $000^{\mathrm{b}}$ \\
& Residual & 59,066 & 72 &, 820 & & \\
& Total & 105,387 & 74 & & & \\
\hline
\end{tabular}

a. Dependent Variable: Seleksi Tenaga Kerja

b. Predictors: (Constant), Efektivitas, Produktivitas Karyawan

Sumber : Data primer, 2021 (telah diolah)

Asumsi :

Jika F-hitung lebih besar dari pada F-tabel, berarti terdapat hubungan yang signifikan antara variabel penelitian Seleksi Tenaga Kerja terhadap Produktivtas dan Efektivitas pada karyawan hotel Makassar.

Sebaliknya jika pada F-hitung lebih kecil dari F-tabel, berarti secara simultan atau bersama-sama variabel-variabel tersebut tidak berpengaruh signifikan terhadap Seleksi Tenaga Kerja karyawan hotel Makassar.

Dengan taraf nyata sebesar $5 \%$ atau 0,05 , dimana $\mathrm{dk}$ pembilang $=3-1=$ 2 , dan dk penyebut $=75-3=72$, maka diperoleh F-tabel sebesar 3,12 / (Distribusi F-tabel dapat dilihat pada lampiran 4).

Dari hasil perhitungan dengan menggunakan program SPSS Ver 22.00 diperoleh F-hitung sebesar 28,232. Hal ini menunjukkan bahwa F-hitung > F-tabel yang berarti bahwa terdapat hubungan yang signifikan secara serempak antara variabel penelitian Seleksi Tenaga Kerja terhadap Produktivtas dan Efektivitas pada karyawan hotel Makassar.

\section{Pengujian Parsial (t)}

Untuk menunjukkan seberapa jauh pengaruh satu variabel penjelas atau bebas secara individual dalam menerangkan variasi variabel terikat. Berikut ini akan dijelaskan pengujian masing-masing variabel secara parsial.

Uji t digunakan untuk membuktikan hipotesis dalam hal ini pengaruh variabel Seleksi Tenaga Kerja terhadap Produktivtas dan Efektivitas pada karyawan hotel, dengan taraf nyata sebesar 5\% atau 0,05, dimana derajat kebebasan (degree of freedom) yaitu : $\mathrm{df}=(\mathrm{n}-\mathrm{k})=75-3=72$, sehingga hasil $t$ tabel yang diperoleh adalah 1,66629 (dapat dilihat pada lampiran 5, distribusi tabel t).

Hasil analaisis regresi menggunakan program SPSS Ver. 22.00 diperoleh nilai thitung untuk masing-masing variabel dapat

Corresponding Author: Hendra Gunawan 
dilihat pada tabel 4.14 sebelumnya (tabel coefficients) sehingga pengujian hipotesis secara parsial untuk masing-masing variabel bebas terhadap variabel terikat, perbandingannya dapat dapat dilihat pada tabel 4.17 berikut :

Tabel

Perbandingan Distribusi t-hitung dengan t-tabel

\begin{tabular}{|l|l|l|}
\hline Variabel & t-hitung & t-tabel \\
\hline Produktivitas Karyawan & 2,887 & 1,666 \\
\hline Efektivitas & 3,870 & 1,666 \\
\hline
\end{tabular}

Sumber : Data Primer (Hasil olah data) tahun 2021

Asumsi menyatakan bahwa jika thitung > t-tabel, berarti ada pengaruh singnifikan antara variabel bebas dengan variabel terikat. Dalam hal. Ini berdasarkan tabel 4.17 tersebut dapat diketahui bahwa dari variabel produktivitas karyawan diperoleh nilai t-hitung sebesar 2,887 dimana t-tabel sebesar 1,666 berarti dapat disimpulkan bahwa terdapat pengaruh positif dan signifikan antara produktivitas karyawan dengan seleksi tenaga kerja karyawan hotel Makassar. Dengan demikian hipotesis pertama penelitian yang menyatakan : Diduga bahwa ada pengaruh yang signifikan antara seleksi tenaga kerja terhadap produktivitas karyawan pada karyawan hotel Makassar, "DITERIMA".

Untuk variabel efektivitas diperoleh nilai t-hitung sebesar 3,870 dimana t-tabel sebesar 1,666 berarti dapat disimpulkan bahwa terdapat pengaruh positif dan signifikan antara efektivitas dengan seleksi tenaga kerja karyawan hotel Makassar. Dengan demikian hipotesis kedua penelitian yang menyatakan : Diduga bahwa ada pengaruh yang signifikan antara seleksi tenaga kerja terhadap efektvitas pada karyawan hotel Makassar. "DITERIMA".

\section{E. KESIMPULAN}

Kesimpulan yang dapat peneliti kemukakan dari hasil penelitian ini adalah sebagai berikut :
1. Nilai constanta (a) diperoleh sebesar 6,229 yang berarti bahwa seleksi tenaga kerja pada karyawan hotel Makassar sebesar 6,229 poin tanpa adanya pengaruh variabel produktivitas karyawan dan efektivitas (Y1 dan Y2).

2. Variabel Produktivitas karyawan (Y1) berpengaruh positif terhadap seleksi tenaga kerja $(\mathrm{X})$ dengan nilai koefisien sebesar 0,357 yang berarti bahwa jika terjadi kenaikan tingkat produktivitas karyawan sebesar 1\% maka kinerja karyawan juga akan mengalami kenaikan sebesar 0,357 dengan asumsi bahwa variabel lain (Y2) tetap.

3. Variabel Efektivitas (Y2) berpengaruh positif terhadap seleksi tenaga kerja (X) dengan nilai koefisien sebesar 0,450 yang berarti bahwa jika terjadi kenaikan tingkat efektivitas sebesar 1\% maka kinerja karyawan juga akan mengalami kenaikan sebesar 0,450 dengan asumsi bahwa variabel lain (Y1) tetap.

4. Hasil perhitungan koefisien determinasi regresi diperoleh nilai adjusted $R$ square sebesar 0,440. Hal ini menunjukkan bahwa sebesar $44 \%$ seleksi tenaga kerja pada karyawan hotel Makassar dipengaruhi oleh variasi kedua variabel, yaitu Produktivitas Karyawan (Y1) dan Efektivitas (Y2), Sedangkan sisanya sebesar 56\% dipengaruhi oleh variabel variabel lainnya yang tidak diteliti. 
5. Dari hasil perhitungan dengan menggunakan program SPSS Ver 22.00 diperoleh F-hitung sebesar 2,232. Hal ini menunjukkan bahwa F-hitung > F-tabel yang berarti bahwa terdapat hubungan yang signifikan secara serempak antara variabel penelitian Seleksi Tenaga Kerja terhadap Produktivtas dan Efektivitas pada karyawan hotel Makassar.

6. Perhitungan uji-t yang digunakan untuk mengetahui pengaruh kedua variable bebas secara parsial terhadap variabel terikat dimana variabel variabel produktivitas karyawan diperoleh nilai t-hitung sebesar 2,887 dimana t-tabel sebesar 1,666 berarti dapat disimpulkan bahwa terdapat pengaruh positif dan signifikan antara produktivitas karyawan dengan seleksi tenaga kerja karyawan hotel Makassar. Untuk variabel efektivitas diperoleh nilai thitung sebesar 3,870 dimana t-tabel sebesar 1,666 berarti dapat disimpulkan bahwa terdapat pengaruh positif dan signifikan antara efektivitas dengan seleksi tenaga kerja karyawan hotel Makassar.

\section{DAFTAR PUSTAKA}

A.S. Moenir, 2010. Manajemen Pelayanan Umum Di Indonesia.Bumi Aksara : Jakarta. Hlm 88.

Ali Muhidin, Sambas. 2009. Konsep Efektivitas Pembelajaran. [Online]. Tersedia http://sambasalim.com/pendidikan/ konsep-efektivitas-

pembelajaran.html. [12 september 2010].

Bungkaes, H. R., Posumah, J. H., \& Kiyai, B. (2013). Hubungan Efektivitas Pengelolaan Program Raskin dengan Peningkatan Kesejahteraan Masyarakat di
Desa Mamahan Kecapatan Gemeh Kabupaten Kepulauan Talaud. Journal "Acta Diurna".

Darmawan, Didit. 2013. Prinsip-Prinsip

Perilaku Organisasi. PT. Temprina Media Grafika. Surabaya.

Dessler, Gary. 2015. Manajemen Sumber Daya Manusia. Jakarta: Salemba Empat.

Edy, Sutrisno. 2014. Manajemen Sumber Daya Manusia. Jakarta: Kencana Prenada Media.

Falih. S. 2010. Revitalisasi Administrasi Negara. Yogyakarta : Graha Ilmu.

Fayol Henry, 2012. dialih bahasa M Ladzi Safroni, Manajemen Reformasi Pelayanan Publik.

Handoko, T. Hani. 2011. Manajemen Personalia dan Sumberdaya Manusia. Yogyakarta: Penerbit BPFE.

Hasibuan, Malayu S.P, 2006, Manajemen Dasar, Pengertian, dan Masalah,Edisi Revisi, Bumi Aksara:Jakarta.

2012. Manajemen Sumber Daya Manusia. Terjemahan. PT. Prenhallindo, Jakarta.

Manajemen. Edisi revisi, cetakan ke 10. PT. Bumi Aksara, Jakarta.

Ardana, Komang dkk. (2012). Manajemen Sumber Daya Manusia. Graha Ilmu. Yogyakarta.

Jackson, Agustin, R. P. (2014). Hubungan antara produktivitas kerja terhadap pengembangan karir pada karyawan PT Bank Mandiri Tarakan. eJournal Psikologi, 02(01), 24 - 40. 
Khaerul. Umam. 2010. Perilaku Organisasi. Bandung: Pustaka Setia

M. Manullang, 2012. Dasar-dasar Manajemen Bagi Pimpinan Perusahaan. Jakarta. Gajah Mada Press.

Mangkuprawira dan Hubeis. 2014. Manajemen Mutu Sumber Daya Manusia.

Maurits, L. 2010. Selintas Tentang Kelelahan Kerja. Yogyakarta: Amara Books.

M. nazir. 2002. Metode Penelitian. Jakarta : Ghalia Indonesia.

Nawawi, Gaol. (2014). Manajemen Sumber Daya Manusia. Jakarta: Grasindo

Pasolong, Harbani. 2010. Teori Administrasi Publik, Alfabeta, Bandung.

Ravianto, Masruri. 2014. Analisis Efektifitas Program Nasional pemberdayaan masyarakat mandiri perkotaan. Padang: Akademia Permata.

Richard, M. Steers, 1980, Efektivitas Organisasi, Erlangga, Jakarta.

Rivai, Veithzal dan Sagala, Ella Jauvani. 2009. Manajemen Sumber Daya Manusia untuk Perusahaan dari Teori ke Praktik. Jakarta: PT Raja Grafindo.

Robbins, Stephen P. and Mary Coulter. (2012). Management, Eleventh Edition, (United States of America: Pearson Education Limited).

Ronald O'relly. 2003. Manajemen Sumber Daya Manusia. Jakarta : Prestasi Pustaka.

Sarjono, Julianita, Haryadi, Winda. (2011). SPSS vs LISREL : sebuah pengantar, aplikasi untuk riset.
Salemba empat : Jakarta.

Schein dan Rosseau, 2010, Psychological

Contract Inventory Technical

Report, USA:Cahnegie Mellon University.

Siagian, P. 2002. Kiat Meningkatkan Produktivitas Kerja. Jakarta : PT Rineka Cipta.

Simamora, Sutrisno. 2015. Manajemen Sumber Daya Manusia. Cetakan ke-9. Jakarta: Kencana

Sinungan, Muchdarsyah. (2014). Produktivitas: Apa dan Bagaimana. Jakarta : Bumi Aksara.

Soetopo, Hendyat dan Soemanto, Wasty. 1991. Pembinaan dan Pengembangan Kurikulum: Sebagai Substansi Problem Administrasi Pendidikan. Jakarta: Bumi Aksara.

Sugiyono. 2014. Metode Penelitian Pendidikan Pendekatan Kuantitatif, Kualitatif Dan $R \& D$. Bandung: Alfabeta.

Teguh, Ambar, Sulistyani, 2009. Manajemen Sumber Daya Manusia, Graha Ilmu, Yogyakarta.

Tohardi, Edy, Sutrisno. 2011. Manajemen Sumber Daya Manusia. Jakarta: Kencana Prenada Media.

Torang, Syamsir. 2012. Metode Riset Struktur Dan Perilaku Organisasi. Bandung : Penerbit Alfabeta. 